\title{
The Effect of Mineral Composition for Diagenesis and Reservoir Physical Property of Ordos Basin-in Case of Chang 7 Reservoir in Jiyuan Area
}

\author{
Wang wei ${ }^{1.2 .3}$, Zhu yushuang ${ }^{1.2}$, Chen Dayou ${ }^{1.2}$, Wei chengyang ${ }^{3}$ \\ ${ }^{1}$ State Key Laboratory of Continental Dynamics, Northwest University, Xi' an, Shaanxi 710069, \\ China; \\ 2 Department of geology, Northwest University, Xi' an, Shaanxi 710069, China; \\ ${ }^{3}$ PetroChina Changqing Oilfield Company, Xi'an, Shaaxi710021,China
}

Keywords: Ordos Basin; Rock Chang 7; Reservoir

\begin{abstract}
According to comparison research for mineral composition, diagenesis and reservoir characteristics of different dispositional provenance in Jiyuan area of Ordos Basin. The results show that: the difference of rock lead to the difference of its matrix mineral composition and interstitial material composition, and its diagenesis environment and diagenesis are different. The research area can be divided into northeast area and northwest area basing on the dispositional provenance. Mineral compositions of two areas are different. For northeast area, the content of feldspar and chlorite is high, and the content of quartz, illite, kaolinite, carbonate and silicoide is low. While for northwest area, the content of feldspar and chlorite is low, and the content of quartz, illite, kaolinite, carbonate and silicoide is high. Therefore, the reservoir physical property of northeast area is high, whose compaction, pressolution and cementation is weak, and corrosion is strong. While the reservoir physical property of northwest is low, whose compaction, pressolution and cementation are strong, and corrosion is weak.
\end{abstract}

\section{Introduction}

Ordos Basin as a stable cratonic depression basin, is rarely affected by tectonic movements, and its reservoir characteristics are mainly affected by sedimentation and diagenesis ${ }^{[1]}$. Because the sedimentary environment and mineral compositions of rocks are different, diagenesis and reservoir characteristics of different regions are not the same. In this paper, through various means of cast slice, SEM and pore structure test, we carry out comparative study on the characteristics of petrology and diagenesis, pore type, interstitial material of different sediment source reservoir under the same sedimentary environment, and analyze the effect of framework mineral composition and interstitial material on diagenesis and reservoir physical properties, which will provide important theoretical basis for further oil and gas exploration and reservoir prediction

\section{Area Information}

Jiyuan area is located in the southwest of Ordos Basin, crossing the northern slope and Tianhuan depression belt. Affected by the Indosinian movement, in the late Triassic, there were ever lakes in the south of Ordos Basin ${ }^{[2,3]}$. In the late Paleozoic, on the back of the Yinshan Basin and Northwest of Alashan Basin, the long-term denudation became the main provenance area ${ }^{[4-7]}$. The resource of research area mainly includes two directions of northeast and northwest. Accordingly, the research area can be divided into northeast area and northwest area.

\section{Mineral Composition Features}

Rock minerals. According to the observation under cast thin section microscope, Rock Chang 7 is mainly very fine - grained lithic feldspar sandstone. The quartz content is $28.15 \%$; the feldspar content is $35.71 \%$; the lithic content is $19.32 \%$, and the components in different area are different, as shown in Tab. 1. 
Tab.1 Material component for sandstones of the Chang7 r0065servoir in Jiyuan area

\begin{tabular}{|c|c|c|c|c|c|c|c|c|}
\hline \multirow{3}{*}{$\begin{array}{c}\text { Horizo } \\
\mathrm{n}\end{array}$} & \multirow{3}{*}{ Area } & \multicolumn{5}{|c|}{ Debris content (\%) } & \multirow{3}{*}{$\begin{array}{c}\text { Interstitial } \\
\text { material (\%) }\end{array}$} & \multirow{3}{*}{$\begin{array}{c}\text { Statistical } \\
\text { sample } \\
\text { number }\end{array}$} \\
\hline & & \multirow[b]{2}{*}{ Quartz } & \multirow{2}{*}{$\begin{array}{l}\text { Feldsp } \\
\text { ar }\end{array}$} & \multicolumn{3}{|c|}{ Debris } & & \\
\hline & & & & $\begin{array}{c}\text { Magmatic } \\
\text { rocks }\end{array}$ & $\begin{array}{c}\text { Sedimenta } \\
\text { ry rocks }\end{array}$ & $\begin{array}{c}\text { Metamorph } \\
\text { ic rocks }\end{array}$ & & \\
\hline \multirow{3}{*}{$\begin{array}{c}\text { Chang } \\
7\end{array}$} & $\begin{array}{c}\text { Northeas } \\
t\end{array}$ & 27.33 & 38.84 & 3.59 & 9.51 & 5.69 & 14.56 & 145 \\
\hline & $\begin{array}{c}\text { Northwe } \\
\text { st }\end{array}$ & 29.61 & 30.17 & 2.6 & 12.19 & 5.33 & 16.6 & 82 \\
\hline & Average & 28.15 & 35.71 & 3.23 & 10.48 & 5.56 & 15.3 & 227 \\
\hline
\end{tabular}

Compared with northeast area, the quartz content of northwest area is slightly higher (29.61\%); feldspar content is lower (30.17\%); debris content is higher $(20.12 \%)$; the rock types are basically consistent with northeast area, which are mainly lithic feldspathic sandstone and a small number of long-lithic sandstone (as shown in Fig. 1-b). Compared with the sandstone lithic of northeast area, its magmatic rocks content is relatively lower $(2.60 \%)$, and sedimentary rocks content is relatively higher (12.19\%).

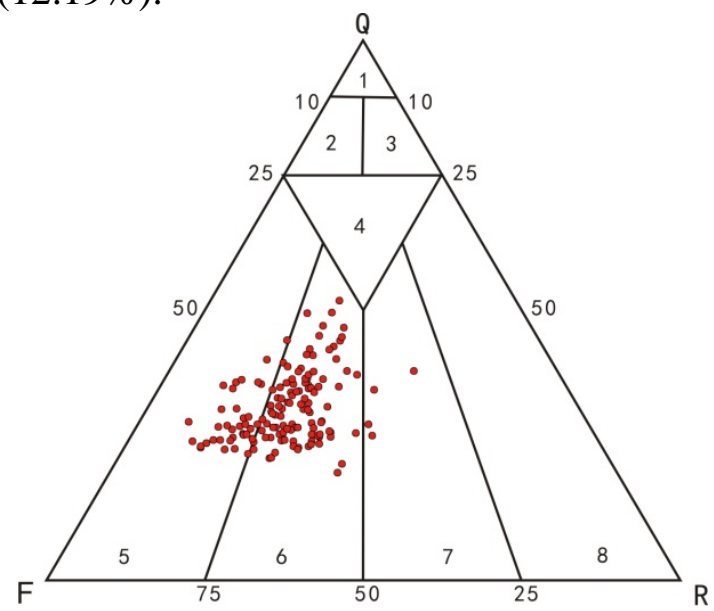

(a) northeast area

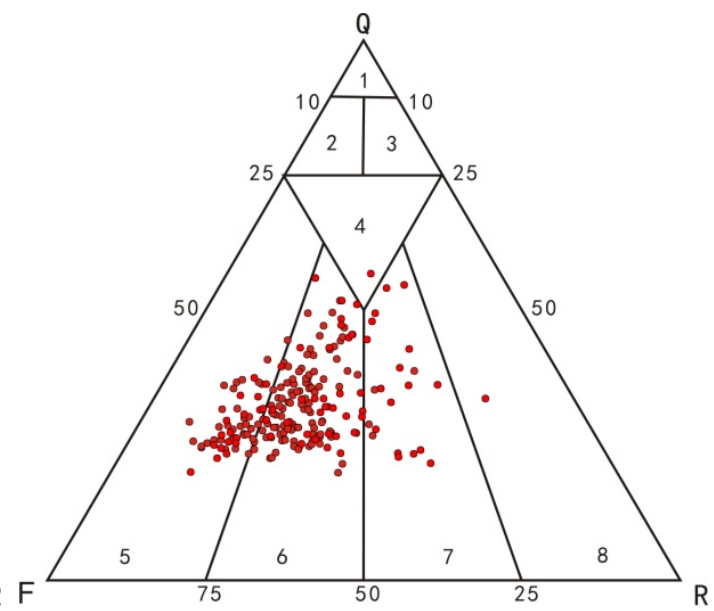

(b) northwest area

Fig. 1 Classification plot for sandstones of chang7 formation in Jiyuan area (after Folk, 1974)

Interstitial material. The average interstitial material content of rock chang 7 in research area is $15.30 \%$. There are various types of interstitial material, which are mainly authigenic clay minerals and carbonates, and a small amount of silica and other minerals as well (as shown in Tab. 2). Among them, the authigenic clay minerals are mainly kaolinite (1.89\%), illite (3.83\%), chlorite (2.00\%); while the carbonates are mainly ferrocalcite (3.66\%) and ankerite (1.18\%).

Tab.2.Interstitial material component of the Chang7 reservoir in Jiyuan area

\begin{tabular}{|c|c|c|c|c|c|c|c|c|}
\hline \multirow{2}{*}{$\begin{array}{c}\text { Horizo } \\
\mathrm{n}\end{array}$} & \multirow[b]{2}{*}{ Area } & \multicolumn{3}{|c|}{ Clay mineral (\%) } & \multicolumn{2}{|c|}{ Carbonate minerals (\%) } & \multirow{2}{*}{$\begin{array}{c}\text { Siliceous } \\
\text { (\%) }\end{array}$} & \multirow{2}{*}{$\begin{array}{c}\text { Others } \\
(\%)\end{array}$} \\
\hline & & $\begin{array}{c}\text { Kaolinit } \\
\text { e }\end{array}$ & Illite & Chlorite & Ferrocalcite & Ankerite & & \\
\hline \multirow{3}{*}{$\begin{array}{c}\text { Chang } \\
7\end{array}$} & $\begin{array}{c}\text { Northea } \\
\text { st }\end{array}$ & 1.8 & 3.48 & 2.47 & 4.2 & 0.8 & 0.79 & 1.02 \\
\hline & $\begin{array}{c}\text { Northwe } \\
\text { st }\end{array}$ & 2.05 & 4.6 & 1.16 & 3.59 & 1.84 & 1.11 & 2.25 \\
\hline & Average & 1.89 & 3.83 & 2 & 3.66 & 1.18 & 0.9 & 1.84 \\
\hline
\end{tabular}

By comparing filling contents in different regions, we can see that, chlorite content in northeast area is higher; while contents of kaolinite, carbonate and siliceous in northwest area are higher than northeast area. Interstitial material compositions in different area are also different, which affects the intensity of diagenesis and transformation of reservoir. 


\section{Diagenesis and Its Effect on Reservoir}

Compaction and pressolution. Compaction and pressolution happen in the early diagenetic stage and the late diagenetic stage, which are the main diagenesis to reduce the reservoir properties. The sandstones in research area are mainly lithic feldspathic sandstone and feldspathic sandstone. Performance of compaction is intimate contact between the particles of debris, which is mainly linear contact (as shown in Fig. 2-a). In addition, mica strip as false hybrid glycosylated is extruded into the pores between grains (as shown in Fig. 2-b). For the sandstone with chlorite film development, because the chlorite films formed in early diagenesis has protected the primary porosity, and wrap the particles, so that effectively prevent attachment growth of pressolution-formed quartz in the grains, and reduces the damage of pressolution to the pore ${ }^{[8-12]}$.

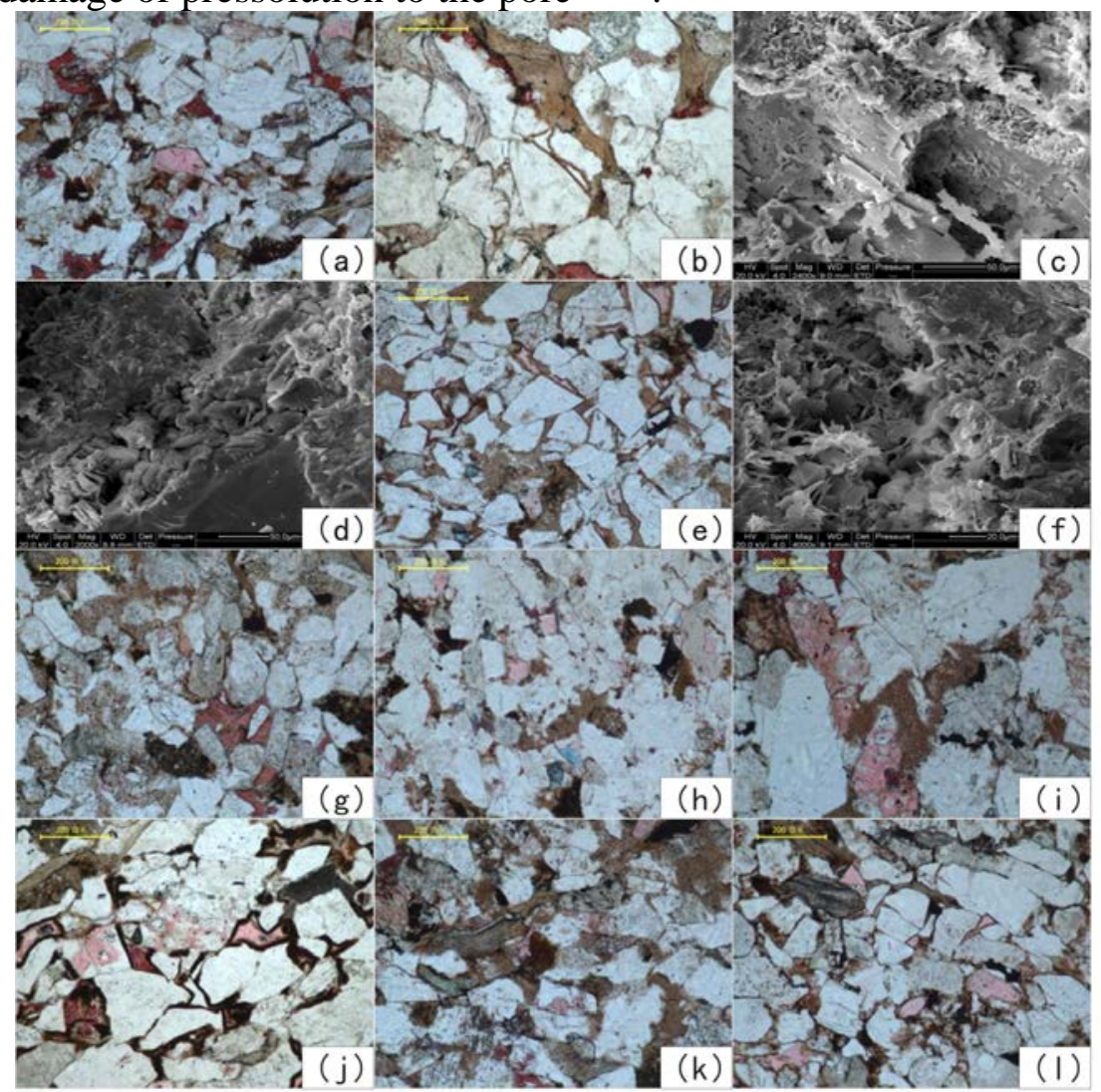

Fig.2 Characteristics of reservoir diagenesis under microscope of Chang7 in research area

Cementation. The cementation in research area is mainly clay mineral cementation, carbonate cementation and siliceous cementation.

(1) Clay mineral. Through cast slice, SEM and X diffraction, the clay minerals in research area are mainly kaolinite, illite and chlorite. Chlorite is mainly in the form of clay membrane with pore lining (thickness of which is about $4 \sim 10 \mu \mathrm{m}$ ). The existence of chlorite films protects the residual intergranular pore (as shown in Fig. 2-c). Pore radius in the region of chlorite growth is relatively large, with good connectivity.

Kaolinite is mainly produced in the form of pore filling, and authigenic kaolinite fills in intergranular pore or intragranular holes in the form of wormlike aggregates (as shown in Fig. 2-d). Kaolinite aggregates filling in the pores will often cause pores between rock grains are filled, reducing the original inter-particle porosity, which makes deteriorated reservoir ${ }^{[14,15]}$.

(2) Carbonate minerals. Carbonate cementation is the most important cementation in research area, with high content, mainly including ankerite and ferrocalcite. Ferrocalcite is mainly even crystalline calcite $(50 \sim 100 \mu \mathrm{m})$ filling pore (as shown in fig. 2-g), and a few of it is fine crystalline $(5 \sim 20 \mu \mathrm{m})$ metasomatic clastic particles and matrix. Ankerite is in the form of Fine crystalline $(5 \sim 20 \mu \mathrm{m})$, with filling pore or metasomatic clastic particles (as shown in Fig. 2-h). 
(3) Authigenic siliceous minerals. Authigenic siliceous minerals are mainly quartz overgrowth edge and other shape filled quartz. Quartz overgrowth edge is form in the early diagenesis stage, which is attached to the quartz grains epitaxial in the form of overgrowth edge (as shown in Fig. 2-j); other shape quartz is formed in the late diagenesis stage, separating out because of water participation (as shown in Fig. 2-l).

Dissolution. Dissolution is the main dissolution formed by secondary porosity in research area, and is also the most important diagenesis to improve reservoir property. Formation of dissolution pores requires three conditions: 1 ) A certain number of primary porosity; 2) presence of acid-soluble components of the rock; 3) presence of acidic fluid.

\section{Pore Types of Reservoir and Physical Difference}

Pore types of Rock Chang 7 in research area mainly include intergranular pore, feldspar dissolved pore, debris dissolved pore and a small amount of microfractures, etc. (as shown in Tab. 3), with $2.12 \%$ of average surface-pore rate.

Tab.3.Interstitial material component of the Chang7 reservoir in Jiyuan area

\begin{tabular}{|c|c|c|c|c|c|c|c|}
\hline \multirow[b]{2}{*}{ Horizon } & \multirow[b]{2}{*}{ Area } & \multicolumn{4}{|c|}{ Surface-pore rate $/ \%$} & \multirow[b]{2}{*}{$\begin{array}{c}\text { Total } \\
\text { surface-por } \\
\text { e rate } / \%\end{array}$} & \multirow{2}{*}{$\begin{array}{l}\text { Statistical } \\
\text { well } \\
\text { number/bloc } \\
\text { k number }\end{array}$} \\
\hline & & $\begin{array}{l}\text { Intergranul } \\
\text { ar pore }\end{array}$ & $\begin{array}{l}\text { Feldspar } \\
\text { dissolved } \\
\text { pore }\end{array}$ & $\begin{array}{c}\text { Debris } \\
\text { dissolved } \\
\text { pore }\end{array}$ & Others & & \\
\hline \multirow{3}{*}{ Chang 7} & $\begin{array}{c}\text { Northeas } \\
t\end{array}$ & 0.92 & 1.07 & 0.08 & 0.13 & 2.2 & 145 \\
\hline & $\begin{array}{l}\text { Northwe } \\
\text { st }\end{array}$ & 0.87 & 0.81 & 0.09 & 0.16 & 1.93 & 82 \\
\hline & Average & 0.91 & 0.98 & 0.08 & 0.14 & 2.11 & 227 \\
\hline
\end{tabular}

Intergranular pore and feldspar dissolved pore contents in northeast area are higher than northwest area, and the total surface-pore rate is also higher.

Through the research on pore size (as shown in Tab.4), we can see that Chang 7 are mainly small pores, which accounts for $66.33 \%$; followed by micro pores, which account for $22.11 \%$; a few of them are medium pores and fine pores. There are certain differences of pore size between northeast area and northwest area.

Tab.4 Distribution of pore radius of the Chang7 reservoir in Jiyuan area

\begin{tabular}{|c|c|c|c|c|c|c|c|}
\hline \multicolumn{2}{|c|}{ Pore type } & $\begin{array}{l}\text { Large } \\
\text { pore }\end{array}$ & $\begin{array}{c}\text { Medium } \\
\text { pore }\end{array}$ & $\begin{array}{l}\text { Small } \\
\text { pore }\end{array}$ & $\begin{array}{l}\text { Fine } \\
\text { pore }\end{array}$ & $\begin{array}{l}\text { Micro } \\
\text { pore }\end{array}$ & \multirow{2}{*}{$\begin{array}{c}\text { Average } \\
\text { pore } \\
\text { radius/ } \mu \mathrm{m}\end{array}$} \\
\hline Pore $\mathrm{I}$ & dius $(\mu \mathrm{m})$ & $>100$ & $100 \sim 50$ & $50 \sim 10$ & $10 \sim 0.5$ & $<0.5$ & \\
\hline \multirow{3}{*}{$\begin{array}{c}\text { Chan } \\
\text { g } 7\end{array}$} & $\begin{array}{c}\text { Northeas } \\
t\end{array}$ & 0 & 6.82 & 69.7 & 4.55 & 18.94 & 20.56 \\
\hline & $\begin{array}{c}\text { Northwe } \\
\text { st }\end{array}$ & 0 & 4.48 & 59.7 & 7.46 & 28.36 & 15.38 \\
\hline & Average & 0 & 6.03 & 66.33 & 5.53 & 22.11 & 18.82 \\
\hline
\end{tabular}

The micro pore structure in northeast provenance area is better than northwest provenance area, and their properties also have similar characteristics. Through analysis of physical properties of northeast provenance area and northwest provenance area, we can see that there is still certain gap between the physical properties in these two areas (as shown in Tab. 5). On the whole, the average value of the porosity in northeast provenance area is $9.19 \%$, and the average value of permeability is $0.3 \times 10^{-3} \mu \mathrm{m}^{2}$; average value of the porosity in northwest provenance area is $8.37 \%$, and the average value of permeability is $0.24 \times 10^{-3} \mu^{2}$ 
Tab.5 Statistical core physical property of Chang7 reservoir in Jiyuan area

\begin{tabular}{ccccc}
\hline $\begin{array}{c}\text { Horizo } \\
\mathrm{n}\end{array}$ & Area & $\begin{array}{c}\text { Average porosity } \\
(\%)\end{array}$ & $\begin{array}{c}\text { Average permeability } \\
\left(\times 10^{-3} \mu \mathrm{m}^{2}\right)\end{array}$ & $\begin{array}{c}\text { Well } \\
\text { numbe } \\
\mathrm{r}\end{array}$ \\
\hline $\begin{array}{c}\text { Cortheas } \\
\text { t }\end{array}$ & 9.19 & 0.3 & 7 \\
7 & $\begin{array}{c}\text { Northwe } \\
\text { st } \\
\text { Average }\end{array}$ & 8.37 & 0.24 & 45 \\
\hline
\end{tabular}

\section{Reasons for the Differences in Reservoir Characteristics}

Under the same sedimentary background, because of the difference of rock components in different provenance area, it causes the difference of initial pore structure and diagenesis, and the initial pore structure is affected by diagenesis. Finally, the physical properties of reservoir are quite different.

In northeast provenance area, the magmatite rock content is relatively higher; feldspar content in detrital composition is higher; quartz content is lower; chlorite content in fillings is high; illite, kaolinite, carbonate minerals and siliceous minerals contents are relatively lower, so that the diagenesis of compaction, pressolution and cementation is relatively weak, but dissolution is strong, and the micro pore structure and physical properties of reservoir are good.

In northwest provenance area, the sedimentary rock content is relatively higher; quartz content in detrital composition is higher; feldspar content is lower; chlorite content in fillings is high; illite, kaolinite, carbonate minerals and siliceous minerals contents are relatively higher, so that the diagenesis of compaction, pressolution and cementation is relatively weak, but dissolution is strong, and the micro pore structure and physical properties of reservoir are poor.

\section{Conclusion}

(1) Matrix mineral composition and interstitial material composition of reservoir formed in different provenance areas is different. For matrix mineral in northeast area, the feldspar content is high; chlorite content in fillings is high. Such differences of composition have effect on diagenetic stage and diagenetic place, and finally cause different reservoir properties.

(2) In diagenesis, compaction and pressolution are the main diagenesis to reduce physical properties of reservoir. In cementation, carbonate cementation and illite cementation have a great impact on reservoir properties; while dissolution can greatly improve the reservoir properties. Matrix mineral composition and interstitial material composition will affect the diagenesis and its strength.

(3) Compared with northwest area, Feldspar and chlorite content in northeast area are relatively higher; illite, kaolinite, carbonate minerals and siliceous minerals contents are relatively lower, so compaction, pressolution and cementation is relatively weaker, but dissolution is strong. The controlled, micro pore structure and physical properties of reservoir are good.

\section{References}

[1] Bloch S, Lander R H,Bonnell L. Anomalously high porosity and permeability in deeply buried sandstone reservoirs: origin and predictability[J].AAPG Bulletin,2002,86(2):301-328.

[2] Emery D, Meyers K. Ancient sub aerial exposure and fresh water leaching in sandstones[J].Geology, 1990, 18: 1178-1181.

[3] Zhang W Z, Yang H, Li J F, et al. Leading effect of high-class source rock of Chang 7 in Ordos Basin on enrichment of low permeability oil-gas accumulation-Hydrocarbon generation and expulsion mechanism[J]. Shiyou Kantan Yu Kaifa(Petroleum Exploration and Development), 2006, 33(3): 289-293. 
[4] Yang H, Fu J, Wei X, et al. Sulige field in the Ordos Basin: Geological setting, field discovery and tight gas reservoirs[J]. Marine and Petroleum Geology, 2008, 25(4): 387-400.

[5] Tang X, Zhang J, Jin Z, et al. Experimental investigation of thermal maturation on shale reservoir properties from hydrous pyrolysis of Chang 7 shale, Ordos Basin[J]. Marine and Petroleum Geology, 2015, 64: 165-172.

[6] Ding W, Zhu D, Cai J, et al. Analysis of the developmental characteristics and major regulating factors of fractures in marine-continental transitional shale-gas reservoirs: A case study of the Carboniferous-Permian strata in the southeastern Ordos Basin, central China[J]. Marine and Petroleum Geology, 2013, 45: 121-133. 